\title{
Separate counselling services in Norwegian upper secondary schools. A possibility for a collective holistic approach?
}

\author{
Ida Holth Mathiesen ${ }^{1}$ D Hulda Mjöll Gunnarsdottir ${ }^{1}$ (D)
}

Received: 6 October 2020 / Accepted: 8 September 2021 / Published online: 20 September 2021

(c) The Author(s) 2021

\begin{abstract}
Guidance counsellors hold an important role in youth's educational and vocational choices, well-being and future careers. Central Norwegian policy documents recommend dividing counselling practices in schools into two functions: (1) career guidance and (2) educational welfare guidance. Policy documents also promote a holistic view of the pupil and the value of safeguarding the pupils' best interest. This study explores how counsellors interpret these potentially conflicting recommendations for counselling practice. Our findings indicate that counsellors act as streetlevel bureaucrats and interpret the recommendations in relation to professional values and local contexts. Our analysis reveals three perspectives on how separate forms of counselling can be practised. The first view suggests an integrated, holistic approach. The second suggests a collective holistic approach. The third view indicates a reductionistic approach to career guidance. Counsellors appear to base their views on occupational professionalism, with the ideal of guarding the pupils' best interest at its centre. Hence, the different understandings of separate counselling services, a holistic approach and of what is in the pupils' best interest appear significant for implementing the policy recommendations in schools.
\end{abstract}

Keywords Street-level bureaucracy $\cdot$ Career guidance $\cdot$ Holistic approach

\section{Résumé}

Services d'orientation et de conseil séparés dans les écoles secondaires supérieures norvégiennes. Une possibilité pour une approche holistique collective ? Cette étude explore la façon dont les conseiller-ère-s interprètent les recommandations potentiellement conflictuelles des services d'orientation et de conseil séparés

Ida Holth Mathiesen

ida.h.mathiesen@uis.no

Hulda Mjöll Gunnarsdottir

hulda.m.gunnarsdottir@uis.no

1 Department of Social Studies, University of Stavanger, Stavanger, Norway 
et d'une approche holistique pour la pratique de l'orientation et du conseil en Norvège. Nos résultats indiquent que l'interprétation des conseiller-ère-s est en relation avec les valeurs professionnelles et les contextes locaux. Notre analyse révèle trois perspectives sur la pratique de l'orientation et du conseil séparé. Premièrement, une approche intégrée et holistique. Deuxièmement, une approche holistique collective. Troisièmement, une approche réductionniste. Les conseiller-ère-s semblent fonder leur point de vue sur le professionnalisme de leur métier qui vise à préserver le meilleur intérêt des élèves. Par conséquent, les différentes conceptions semblent importantes pour la mise en œuvre des recommandations politiques dans les écoles.

\section{Zusammenfassung}

Getrennte Beratungsdienste in norwegischen Oberstufenschulen. Eine Möglichkeit für einen kollektiven, ganzheitlichen Ansatz? (0174) Diese Studie untersucht, wie Beratende die potentiell widersprüchlichen Empfehlungen von getrennten Beratungsdiensten interpretieren und einen ganzheitlichen Ansatz für die Beratungspraxis in Norwegen. Unsere Ergebnisse zeigen, dass die Interpretation der Beratenden in Beziehung zu professionellen Werten und lokalen Kontexten steht. Unsere Analyse zeigt drei Perspektiven auf die Praxis der getrennten Beratung. Erstens, ein integrierter, holistischer Ansatz. Zweitens, ein kollektiver, ganzheitlicher Ansatz. Drittens, ein reduktionistischer Ansatz. Die Beratenden scheinen ihre Ansichten auf berufliche Professionalität zu gründen, die darauf abzielt, die Interessen der Schüler zu wahren. Die unterschiedlichen Auffassungen scheinen daher für die Umsetzung der politischen Empfehlungen in den Schulen von Bedeutung zu sein.

\section{Resumen}

Servicios de asesoramiento separados en las escuelas secundarias superiores noruegas. ¿Una posibilidad para un enfoque holístico colectivo? Este estudio explora cómo los consejeros interpretan las recomendaciones potencialmente conflictivas de servicios de asesoramiento separados y un enfoque holístico para la práctica del asesoramiento en Noruega. Nuestros resultados indican que la interpretación de los consejeros está en relación con los valores profesionales y los contextos locales. Nuestro análisis revela tres perspectivas sobre la práctica del asesoramiento separado. Primero, un enfoque integrado y holístico. Segundo, un enfoque holístico colectivo. Tercero, un enfoque reduccionista. Los consejeros parecen basar sus puntos de vista en la profesionalidad laboral, dirigida a velar por el interés superior de los alumnos. Por lo tanto, las diferentes concepciones parecen ser significativas para la aplicación de las recomendaciones políticas en las escuelas.

\section{Introduction}

In Norwegian schools, counsellors hold an important role in youth's educational and vocational choices and well-being. Because the counsellor's interpretations of policy form an important basis for guidance practice, the current study explores how counsellors interpret two central policy guidelines. The first guideline is an organisational 
recommendation on how to organise guidance in school, and the second is the regulation for professional codes of conduct amongst guidance counsellors.

The counselling services in Norwegian schools have two defined functions: (1) educational welfare guidance and (2) career guidance. The primary task for career guidance is to provide pupils with information and guidance regarding educational and vocational choices, whilst the primary task of educational welfare guidance is to help pupils experience social and academic success (FKunnskapsdepartementet, 2009). Furthermore, counsellors are expected to focus on both the system for all counselling activity at the school and guidance of individual pupils (Mordal et al., 2015). Most counsellors in the Norwegian school system hold part-time positions as counsellors and part-time positions as teachers (Buland et al., 2014). Since early 2000, policy has promoted separate counselling services (NOU, 2016, p. 7 , p. 154) as the recommended form (Buland \& Havn, 2003; OECD, 2002; St.Meld. nr.16, 2006-2007). Separate counselling services imply splitting career guidance and educational welfare guidance into separate functions that are attended to by different counsellors (Buland \& Havn, 2003). Separate counselling services were initially promoted as a solution for safeguarding career guidance because stakeholders were concerned that this task was being neglected because of the expanding needs in the area of educational welfare guidance, which include pupils mental and social challenges (Buland \& Havn, 2003). The Norwegian Ministry of Education (2009, Sect. 22-1) has stated, 'In order to preserve the pupils' best interests, there should be a holistic view of the pupil and the educational welfare guidance and career guidance should be integrated'. However, there is no specification of how counselling services in schools should be organised to ensure a holistic guidance practice. Currently, the variety in organising is vast; some schools have assigned both functions to the same person (integrated services), whilst others have split the functions across several persons (separate counselling services).

A 'holistic philosophy of counselling emphasises helping "whole" persons' (Betz \& Corning, 1993, p. 137) and seeing career and personal counselling as inextricably intertwined (Krumboltz, 1993, p. 143). Thus, we see a holistic or whole-person approach as a guidance practice where the counsellor recognises the intertwinement of personal challenges and career decisions, treating them as a continuum rather than dichotomous concerns (Krumboltz, 1993; Super, 1993; Zunker, 2012). The holistic perspective is in accordance with Bronfenbrenner's (1977) classical concept of community collaboration, hence promoting a collective-oriented holistic approach. Kettunen and Makela (2019) found that ethical practice amongst others was conceived as stemming from a collaborative orientation. According to Low et al. (2013), collaboration and cooperation are essential to ensure the successful implementation of counselling services. Thomsen (2017) provide interesting ideas on career guidance as a collective practice in communities. Thus, recommendations that promote separating the two main tasks of counselling may create a conflict with regulatory and professional emphasis to achieve a holistic approach towards counselling. To be explicit, regulations provide guidelines on how the counsellors and schools should conduct counselling, whilst policy recommendations to separate the services address how the services should be organised. Nonetheless, how the work is organised has implications for its practice [e.g., Irgens (2010)]. In the gap between 
policy and practice, the decisions made by practitioners influence how policy is realised (Hooley \& Rice, 2019).

According to Watts (2008), most guidance services are the object of and a potential instrument for public policy; he claims that research within the field of career guidance pays little attention to public policy and implementation. Furthermore, Haug et al. (2020b) and Hooley (2019) address the difficulties of policy implementation in the career guidance field in Norway and how policy implementations' depend on professionals' faith and goodwill. This dependence could also be a consequence of policy having interpretative flexibility (Pinch \& Bijker, 1987). Interpretative flexibility is the notion of how something is interpreted into local knowledge and how it is interpreted differently by different actors. This concept is appropriate for guidance counselling because counsellors need to understand policy in relation to their own local context (Frostenson, 2015; Irgens, 2010). This is supported by the Expert committee on the role of teachers (2016, p. 208), which is explicit on how professional communities have an important mediating function in giving meaningful content to external demands and expectations in development and change.

Prior to year 2000 Nordic research in guidance has focused mainly on the sociological aspects of guidance, its societal links and possible impact (Plant et al., 2003, p. 116). As a developing field of research, Haug et al. (2020a) finds a great variance of thematics in the specific context of Nordic guidance counselling. These include reflections on the Nordic model and the notion of career, gender equality and career guidance and professional development of career guidance practitioners, only to mention a few. However, no contributions of the anthology discuss how counsellors' interpretations and understandings affect the implementation of policy recommendations. The aim of the current study is to fill this gap in the literature.

We seek to expand the knowledge about what guides counsellors' professional practices by exploring how counsellors interpret and understand conflicting regulations and policy recommendations. Our approach to exploring this is based on three complementary theoretical contributions. We combine profession theory and the concepts of occupational and organisational professionalism (Evetts, 2009), boundary work (Liljegren, 2012) and hybrid professionalism (Noordegraaf, 2015), here with Lipsky's (1980) theory of street-level bureaucracy and Pinch and Bijker (1987) interpretative flexibility. Lipsky's (1980) contribution is relevant for understanding counsellors' attempts at managing the difficulties and ambiguities in conflicting recommendations. Interpretative flexibility addresses how policy intentions and content can be interpretatively flexible (Pinch \& Bijker, 1987) when counsellors implement them into local school practices (Irgens, 2010). Insight into counsellors' interpretations and professional judgements may give us knowledge about their perspectives and reasoning for-or not-implementing policy. Such knowledge can be important for future policy making, implementation and development in professional guidance practice. Thus, our research question is as follows: How do counsellors interpret and understand the recommendation of separating career guidance and educational welfare counselling in schools?

The theoretical approach of the current study can contribute to novel knowledge of how counsellors in Norwegian schools understand the contradictions in policy. Exploring this can also provide additional knowledge of counsellors' general 
professional rationales for their practices. This will be further elaborated upon after a short introduction to the research on the Norwegian context of school counselling.

\section{School counselling in a Norwegian context}

The core values of Norwegian school counselling are egalitarianism and contain a moral and political commitment to the welfare state (Bakke, 2020; Haug et al., 2020b; Hooley, 2020). New public management (NPM) has a major impact on the world of work and, consequently, on the way career guidance is conceived, practised (Hooley et al., 2018, pp. 5-8; Hughes et al., 2015; Sultana, 2018). Accordingly also the development of education for career guidance professionals (Andreassen et al., 2019). The Norwegian school system is affected by NPM rationales, with a goal-oriented focus on efficiency, quality and the cost-effective delivery of public services (Hooley et al., 2018; Nilsen, 2021). As a result, counsellors in Norway have reported insufficient resources and that extensive goal orientation and standardised numbers of hours for pupils in each subject are obstacles for guidance activities; they have also stated that their work is rated as second in line and a 'time thief' (Mordal et al., 2015 , p. 112). Counsellors understand themselves primarily as the pupils' supporter (Mordal et al., 2015, p. 116). According to Irving (2017, p. 57), there is a degree of flexibility in counsellors' freedom to review, reframe and reposition career/education discourse when organising their work. Also, as argued by Thomsen (2014), flexible career practices that adapt to the needs of participants have the potential effect of greater social justice. Indeed, the room for local variations in forming and developing the counsellor's role is considerable (Buland et al., 2020; Mordal et al., 2015). Further, it is important to notice that understandings of competence have specific meanings in particular contexts (Sultana, 2009). Yet the role itself appears to be complex and stressful (Mathiesen et al., 2014; Mordal et al., 2015). This points towards a knowledge gap concerning counsellors' perspectives of their own professional practice because earlier research contributions in this field appear to have focused mostly on the outcome of guidance practices (Haug et al., 2018).

\section{Guidance counsellors as professional street-level bureaucrats engaged in interpretative flexibility}

To illuminate the guidance counsellors' professionalism within an NPM rationale, Evetts' (2009) ideal forms of professionalism is useful. Evetts (2009) argues that there is a development of two different and contrasting forms of professionalism. Organisational professionalism is manifested in a discourse of control that involves increasingly standardised work procedures and practices. At the other end of the spectrum, occupational professionalism is oriented towards authority and autonomy and emphasises relationships; here, organisational professionalism is more dependent on structures (Evetts, 2009, p. 248). An important difference between these logics is that occupational professionalism builds authority on trust in professionals' education and ethics, whilst organisational professionalism authority is grounded 
in regulations and control (Liljegren, 2012). According to Abbott (1988), this distinction helps when we make sense of professional craft, which is understood as using abstract knowledge to solve specific issues. Practitioners' mandates and tasks are regulated by public policy and local conditions and can be seen as collective actors who manoeuvre within their specific contexts (Abbott, 1988; Liljegren, 2012). This process can be understood in terms of boundary work (Liljegren, 2012), where professions create, maintain and break down boundaries to separate 'us' from 'them' and claim professional turf. Uncertainty of boundaries and a weakening of autonomous spaces appear to attack professional work and harm professional values (Hermstad et al., 2020; Noordegraaf, 2015). Hence, Noordegraaf (2015) suggests the emergence of hybrid professionalism, which arises when professional and managerial principles-here concerning coordination of work, the establishment of authority and the values at stake-come together. Hence, hybrid professionalism occurs when professional and managerial boundaries become blurred, when professional logics are combined and reconfigured and when professionalism and managerialism are combined (Noordegraaf, 2015).

Lipsky's (1980, 2010) concept of street-level bureaucracy can be helpful for understanding how counsellors manage conflicting or ambiguous policy guidelines. Lipsky's contribution provides a framework for understanding professionals' attempts to cope with difficulties and ambiguities. Street-level bureaucrats are 'public servants who work with residents daily and who must constantly make discretionary assessments' (Lipsky, 1980, p. 3). We understand counsellors as streetlevel bureaucrats because their priorities in daily counselling practice put policy into action. Street-level bureaucrats are 'public servants who work with residents daily and who must constantly make discretionary assessments' (Lipsky, 1980, p. 3 ). In addition, 'they cannot do the job according to ideal conceptions of the practice because of the limitations of work structure' (Lipsky, 2010, p. xvii). Street-level bureaucrats' actions, appraisals and priorities determine what services recipients receive (Lipsky, 1980). Furthermore, they are mediators between two worlds that are out of tune: the state and society (Zacka, 2017, p. 24). There is a growing body of policy-focused studies; however, they rarely indicate opposition or resistance to policy aims as street-level practitioners understand them (Brodkin, 2012, p. 944). Tummers and Bekkers (2014, pp. 540-541) find that street-level bureaucrats' discretion influences their willingness to implement policy in two ways. First, discretion allows them to tailor their decisions and practices to the needs of their clients. Second, discretion has a positive effect on bureaucrats' perceptions of client meaningfulness, which strongly influences their willingness to implement policy. The street-level bureaucracy theory is relevant for analysing counsellors' views as they participate in discussions and decision-making about how to organise the counselling services at their schools. In this context, counsellors are actors who translate policy into action; they decide how and in which form pupils receive guidance.

Hence, from their unique professional point of view, counsellors interpret and adjust their local practices to policy and ethical guidelines. Interpretative flexibility (Pinch \& Bijker, 1987) is a notion used to describe how artefacts are interpreted differently by different actors into local knowledge. By this, Pinch and Bijker (1987) mean "not only that there is a flexibility in how people think of or interpret artefacts 
but also that there is flexibility in how artefacts are designed'(p. 40). They further hold that 'a problem is defined as such only when there is a social group for which it constitutes a "problem"' (Pinch \& Bijker, 1987, p. 30). Buland (1996) shows how interpretative flexibility can be used to understand how policy is interpreted differently by different actors when applying the concept to the analysis of the implementation of new technology in Norwegian public sector. Applying the concept of interpretative flexibility in the current study provides access for exploring counsellors' responses to policy and offers insights into how policy is interpreted differently in this field. In the counsellor context, policy needs to be operationalised within the schools where the counsellors work [e.g., Frostenson (2015), Irgens (2010)]. Thus, when policy recommendations are not clearly formulated, they have interpretative flexibility. Counsellors practice within different local contexts and, therefore, might have different understandings of both policy content and intentions. This is supported by Frostenson's (2015) discussion on how the local organisational context impacts professional autonomy. Also, Rosvall (2019) emphasises the importance of local conditions for pedagogic practice. In extension, Irgens (2010, pp. 133-134) emphasises how 'a good school is not created by individual work alone' and that 'the teachers at collectively oriented schools are more positive about collaboration than their colleagues at individually oriented schools'. Thus, policy's interpretative flexibility might result in different practices and understandings.

Counsellors are a part of the Norwegian school system and engage with pupils on a daily basis as street-level bureaucrats (Lipsky, 1980); they convert policy into action within institutions governed by neoliberalistic goal orientation. In some respects, they are in limbo between their organisational professionalism and occupational professionalism (Evetts, 2009). They use their professional knowledge to analyse each pupil's needs and devote specific meaning to their observations through their professional craft (Abbott, 1988). Furthermore, counsellors are largely left to their own assessments to balance between different expectations. However, both separate counselling services and a holistic approach are interpretatively flexible (Pinch \& Bijker, 1987) concepts that counsellors must interpret into their local context (Irgens, 2010).

\section{Method}

\section{Participants}

Thirty-five guidance practitioners representing 18 upper secondary schools in Norway participated in the interviews. The participants practised guidance for pupils between the ages of 16 and 19. Table 1 provides an overview of the participants' professional responsibility.

The 35 participants were from schools with both integrated and separate counselling services. Sixteen participants practised integrated services, 11 practised only career guidance, and four practised only educational welfare counselling. In addition, there were three counselling service leaders and one participant from the 
Table 1 Participants' areas of responsibility

\begin{tabular}{lc}
\hline Area of responsibility & $\begin{array}{l}\text { Number of } \\
\text { participants }\end{array}$ \\
\hline Career guidance & 11 \\
Educational welfare guidance & 4 \\
Integrated services & 16 \\
Leadership/follow-up services & 4 \\
Total number of participants & 35
\end{tabular}

follow-up service ${ }^{1}$ (see Table 1). Their experience as counsellors varied from 1 to 15 years. The data originate from two research projects: an evaluation project of quality in counselling services in three counties (Buland et al., 2014) and a project on the counsellor's role in schools (Mordal et al., 2015). The interview guides were almost identical. This means that the interviews were part of a wider research context where other thematics were also researched. Although, the data were rich in information when it came to the counsellors' understanding and interpretation of separate counselling services, the two original projects' time limits did not provide the possibility to explore this theme in depth. Research assistants transcribed the interviews. Not having transcribed the material ourselves, made the coding and analysis process more extensive. The research was conducted in accordance with research ethical principles for gathering and saving data and was approved by the Norwegian Centre for Research Data. The transcribed interviews were anonymised and stored for further research, for which the interviewees gave their informed consent.

\section{Focus group}

The data of the current study were collected through focus groups. A focus group method was chosen because participants' discussions could produce data that would not have been possible otherwise (Morgan, 2019, p. 5) and because of its capacity for exploring the logic of the phenomenon (Demant, 2006), that is, counsellors' reflections and understanding of school guidance. Data were generated through the participants' discussions and were determined and guided by the researchers (Morgan, 2019). We conducted focus groups according to a funnel-shaped strategy (Morgan, 2019, pp. 68-69) on nine predefined topics. Because of the small size of three schools, three of the interviews had only two participants. These three interviews, with two participants each, differ from the majority interviews by being more of a guided conversation rather than a discussion (Morgan, 2019). We conducted 10 focus group interviews and two individual interviews.

\footnotetext{
1 The follow-up services are responsible for the pupils who have dropped out of school or are in danger of dropping out. Their main concern is getting these pupils into meaningful activity, whether it is work or education. This requires both career guidance and educational welfare guidance.
} 


\section{Analyses}

We have analysed the data following an abductive approach (Timmermans \& Tavory, 2012, p. 180), which is understood as a systematic process of meaning-making aimed at theoretical generalisations that nurture theoretical pluralism (Tavory \& Timmermans, 2014, p. 123). Analyses were conducted by looking at the interaction between data and theory, and different categories have emerged from this interaction. The interviews were coded with a thematic analysis approach (Morgan, 2019), here with the intent of interpreting the meaning and creating codes that captured the discussed themes. We applied codes manually using NVivo to organise the data and obtain an overview.

During the interviews, reflections on separate versus integrated counselling services kept emerging. This caught our attention and made us interested in exploring the counsellors' views on this policy recommendation. The interviewees provided rather strong opinions on the subject, which gave us the notion that this was an important point from which the counsellors defined their professional practice. Further, whilst making their arguments-for or against separate counselling services - they frequently started discussing what was in the pupils' best interest in general. Further, the discussions of the pupils' best interests brought in the concept of a holistic view. As the findings in the next sections will show, a holistic view can both be related to a holistic view of the pupil and the holistic view of the counselling practice, implying that the counsellors have different points of departure for their arguments for or against separate counselling services. We will elaborate on this in the following section, where we present the findings.

\section{Results}

When asking counsellors how they felt about separate counselling services, we noticed that the views on how to organise the two functions of counselling services in Norwegian schools and the counsellor's basic values were closely intertwined. Three different lines of argument dominated their responses: (1) integrated counselling, a holistic approach; (2) separate counselling, a collective holistic approach; and (3) separate counselling, a reductionist approach. In the following, we will describe these three views, as discussed in the focus groups.

\section{Integrated counselling, a holistic approach}

The first stance comprised counsellors who were negative when it came to separate counselling services. They were concerned about safeguarding holistic values in counselling and expressed scepticism towards the separation of the services, regardless of how it was organised. One counsellor in a focus group said, 'Educational welfare, career guidance and future planning are all closely connected'. The rest of the focus group acknowledged her viewpoint. This view resembles a holistic approach. She explained, 'It's like this: when a pupil comes to us, then he comes with an easy 
question and a harmless problem, but it turns out to have a more complex background'. The counsellor further argued that when counsellors' functions are integrated as one person's responsibility, it is easier for the counsellor to safeguard the whole pupil. One counsellor stated that 'an individual is a whole after all, and then, it is both the educational welfare and [career guidance] [...] everything is connected, you know'. This indicates flexibility as a prerequisite for the services. It also appears to highlight the importance of addressing concerns about how separating services could affect the accessibility of both career guidance and social welfare guidance to pupils. The counsellors who supported this stance appeared to assume that separate counselling services would equal little collaboration between the functions. Furthermore, they seemed to believe that integrated services were the only way to safeguard the pupils' best interests and a holistic approach. One counsellor explained, 'We follow the pupils. The whole pupil. We think it is an unnatural choice to separate educational welfare and career guidance'. Their assumption of separate counselling as a limitation regarding seeing the whole pupil led to their professional consideration of separate counselling services as a poor way to organise the services. Thus, this stance appears to gather a holistic view of the pupil, a holistic approach to counselling services and safeguarding the pupils' best interests in general, as integrated, intertwined and interdependent parts of counselling as professional practice.

\section{Separate counselling, a collective holistic approach}

The second line of arguments was positive towards separate counselling with extended collaboration found in teams of counsellors. The different parts of the team would safeguard different functions, thus securing a holistic approach towards the pupils and counselling. In one focus group, the following statement about experience with separate counselling was presented and gained consensus:

It works well. It is effective. Because we use each other, [...] as a 'happy street', right? Including all pupils' services, counsellors, practical pedagogical services, the follow-up services, the health nurse and so on. We all sit over here together, and then, we can use each other so much more. [...] It is much more effective when we can use our competence on the pupil instead of having to sit with everything ourselves.

In her case, all the student services were colocated, which made it easier to collaborate and offer different expertise to the pupils. Collaboration was essential in the provision of counselling services to pupils. In another focus group, a counsellor argued this in the following way: 'I believe that we can work with the same person in different ways. [...] And then we balance it'. It appeared to be important to have a balance between the functions, thus safeguarding all aspects of a pupil's life through teamwork. This stance views separate counselling as positive yet with a holistic approach to counselling through extensive cooperation. The counsellors clarified this view in a focus group: 'There can't be watertight bulkheads because, [...] it must be a collaboration. The fact that both [functions] may well join in when we have summoned a meeting and then get the overall picture [is crucial]'. These counsellors 
were concerned about how to collaborate to ensure a holistic approach; they presupposed that separate counselling denoted collaboration between functions.

At another school, they explained how they work: 'We have our clear areas, but it is the sharing culture that is so important to be able to be together in holistic thinking'. Thus, these counsellors valued the need to see the whole pupil and were positive towards separate counselling. Yet this approach depended on collaboration and could lead to performing tasks not formally assigned to their function. In one focus group, a counsellor told us, 'Pupil issues are often a volunteer job. Everyone must contribute. Often, you may need to do a thing that may not be within your job description. That's because it's no doubt who's in focus: it is the pupil'. She valued separate services because 'with separate counselling services, you get the opportunity to specialise in your field'. According to this, separate services can contribute to counteracting resource scarcity and creating room for personal development through interpretative flexibility. This suggests that separate counselling services with extensive collaboration can safeguard a holistic approach to counselling and pupils.

\section{Separate counselling, a reductionistic approach}

The third stance suggests that a separation of the services could shield career guidance from the extensive need for educational welfare guidance. This was one argument for separate counselling services in NOU 2016:7. Limited resources appeared to cause frustration amongst the counsellors, and separate counselling services were suggested as a possible solution. One counsellor addressed this in a focus group:

It [career guidance] does not get better until we separate the counselling services. [...] as it [the resource situation] is now, I see no other solution than simply having to have waterproof bulkheads [...] between the services [educational welfare and career guidance]. For here, one cannot manage to shield the career guidance at all as it is now - [with] emergency cases all the way within the educational welfare guidance.

His statement indicates an overwhelming workload within educational welfare guidance, and he was supported in the group discussion. Some informants expressed scepticism towards a holistic approach. This group argued that a counsellor does not need to know everything about a person to provide guidance. One career counsellor stated the following during a focus group:

It was good for them to come here just to talk about educational choice, not to talk about 'how do you feel inside now' [...] that part was put away, so we only talked about their resources for further education.

The interviewee valued the opportunity to represent a place where the students could talk about their future in a positive setting without having to address other difficulties in their lives, which was understood as of little importance when it came to career guidance. She argued that a holistic approach should be voluntary and that a reductionistic approach is sometimes in the pupils' best interest. Further, this argumentation promoted separating counselling services on the grounds of a need for 
professionalising the services. These counsellors were concerned about developing the skills and practices of counsellors. In a focus group, they argued, 'We talk of professionalisation, you know. [...] If we are going to get better in our functions, then of course we must have a separation. We cannot be equally good in both areas'. The reasoning was that the separation makes room for focus and professional development. Furthermore, as one participant stated, 'You get more time for career guidance, you know... educational welfare guidance takes all the time and is very unpredictable'. This can also be connected to counsellors safeguarding their own work environments and mechanisms for handling extensive workloads.

\section{Interpretative connections}

Our findings indicate that negative or positive attitudes towards separate counselling can be explained by the combination of interpretations regarding the implications of separate counselling services for a holistic approach. Table 2 depicts the contextualised analysis of the holistic versus reductionistic approach to guidance in the context of separate or integrated services.

As seen in Table 2, in the first combination, the counsellors were negative towards separate counselling services and appeared to assume that this organisational form equals no collaboration between the various functions. This stance viewed integrated services as the only way to safeguard a holistic approach in the pupils' best interests. The second combination represents counsellors who were positive towards separate counselling but with extensive collaboration. They believed that several counsellors could collectively safeguard a holistic approach. The third combination was counsellors who promoted separate counselling services, arguing that a reductionistic approach with room for focusing solely on career guidance was in the best interest of pupils.

\section{Discussion}

In the following, we discuss our findings in the light of professionalism, interpretative flexibility and street-level bureaucracy. The analysis shows that a holistic approach (Betz \& Corning, 1993; Krumboltz, 1993; Zunker, 2012) has several nuances to it, and we argue that we can see the outlines of two slightly diverse understandings because of the interpretative flexibility (Pinch \& Bijker, 1987) of the concept. Thus, the implementation and understanding of holistic approaches in counselling appear to depend on the local context. The third understanding of best practices in counselling resembles a reductionist approach.

\section{Holistic approach}

The emphasis on a holistic view appeared in many of our interviews. However, the counsellors did not define this concept, other than stating that it is a central aspect of good professional practice. Yet the holistic approach appears to represent a holistic 


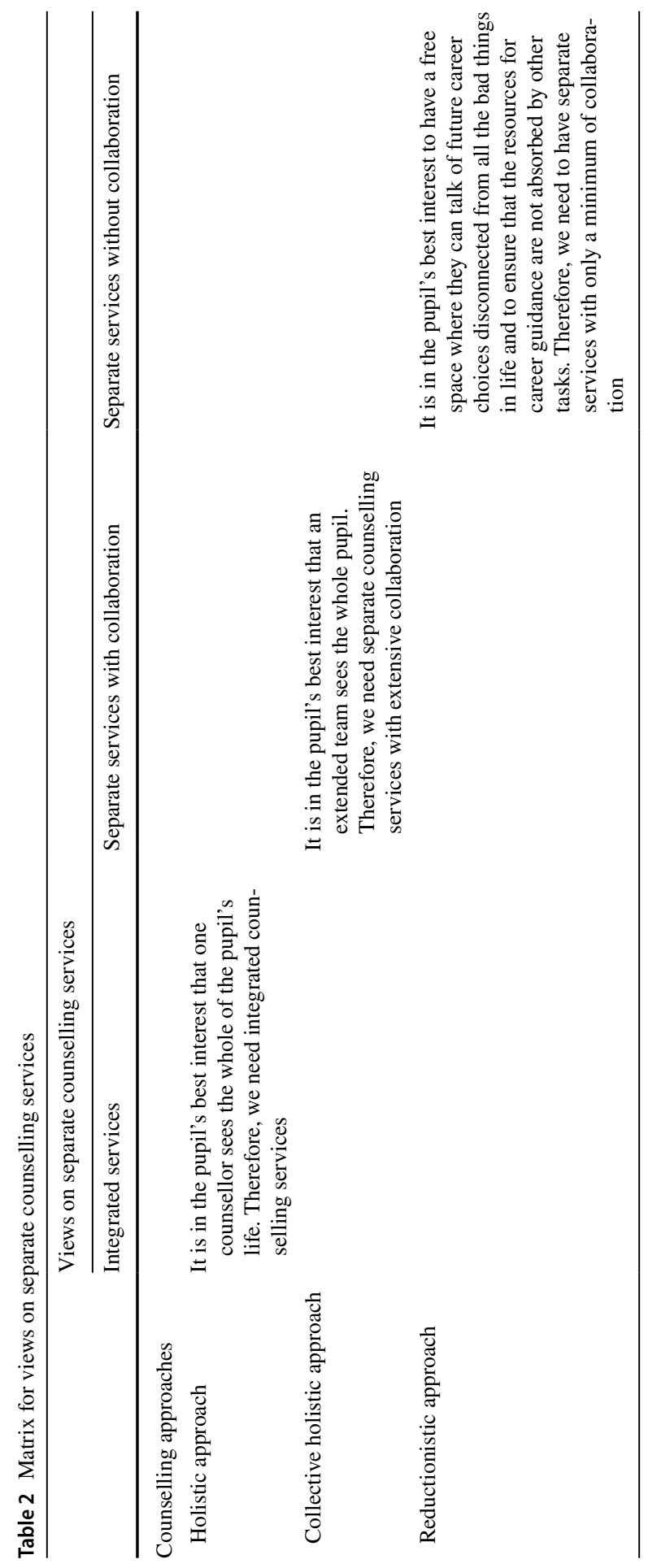


view of the pupil. This is similar to how the holistic approach is defined in the literature as career and personal counselling being inextricably intertwined (Krumboltz, 1993) and not easily separated on different persons. Thus, the holistic approach constitutes a pupil-centred holistic approach, where the counsellors aim to take all aspects of the pupils' lives into account during counselling. This implies that each counsellor's professional turf includes both educational welfare and career guidance.

The collective holistic approach also emphasises a holistic view, yet it seems to orient more towards a holistic view of counselling. A collective approach to counselling can safeguard both career and educational welfare through teamwork. This interpretation facilitates collective counselling services where several counsellors implement holistic counselling through extensive collaboration. The implication of this interpretation is that it allows counsellors to specialise in specific areas whilst still delivering holistic guidance to pupils. One might see it as a combination of a holistic approach (Krumboltz, 1993) and a Bronfenbrenner-inspired (1977) collective holistic approach. The counsellors acknowledged that guidance should take into account the whole pupil's life, and this is solved through collective collaborative efforts. Zunker (2012) uses the term holistic approach when discussing counselling, but as we understand his accounts of it, it is still a 'people-focused' approach. What our analyses reveal is a holistic approach to the whole of the counselling practised in school, not only the counselling of 'whole' pupils. This finding relates to what Low et al. (2013) describe in their context of counselling in schools in Malaysia as the importance of collaboration between school counsellors.

The last and reductionistic approach to career guidance seems to see potential personal and health issues amongst pupils as outside their responsibility. The argument here is that there is no need to know everything about a person to give good career guidance. This appears to be a reductionist approach to counselling and contrary to what Betz and Corning (1993), Krumboltz (1993) and Zunker (2012) define as a holistic approach integrating personal and career guidance. However, this might be more related to resources and NPM than actual differences in professional values. Viewing guidance counsellors as street-level bureaucrats (Lipsky, 2010) who are managing their work situation, as described in Mathiesen et al. (2014), can explain the reductionist approach. In circumstances with scarce resources, the counsellors seem to respond to the requirement of a holistic view by reducing or confining their definition of a holistic approach to career guidance alone. Thus, the reductionist approach may be a strategy for coping with scarce resources and high demands. Yet it might raise concerns about whether the pupils in schools with reductionist approaches toward counselling are receiving guidance in accordance with their legislative rights.

\section{Separate counselling services}

The three understandings of separate counselling services described above can be described as the results of interpretative flexibility (Pinch \& Bijker, 1987). This flexibility is visible in how the counsellors, as street-level bureaucrats (Lipsky, 2010), reflected on the practical consequences of the separation. Separate organising of 
guidance services is interpreted as a threat to occupational professionalism amongst the counsellors who emphasised the value of a holistic approach to the pupil (Evetts, 2009; Liljegren, 2012). Separate services are viewed to be in conflict with professional codes of ethics and in the pupils' best interest (Liljegren, 2012). Thus, these counsellors defined separate counselling services as a problem because they are an organisational measure that can potentially work against their occupational professionalism. Yet their responses can also be viewed in terms of boundary work, here suggesting that 'pupil-oriented' counsellors are using arguments for a holistic approach to claim their professional turf (Liljegren, 2012). However, the scepticism towards separating the services can also be related to resistance to increased organisational professionalism (Evetts, 2009) and a perceived threat to the counsellors' occupational professionalism (Evetts, 2009), accordingly, their authority and autonomy in professional practice. Further, the recommendation to separate can be seen as a further development towards an individualistic orientation in schools (Irgens, 2010).

Further, the counsellors appeared to assume interpretative flexibility in their understanding of how separate counselling services are 'designed' (Pinch \& Bijker, 1987). Our findings indicate two interpretations of the designs. One is separate counselling services with collaboration between educational welfare services and career guidance. This design can be related to occupational professionalism, which is founded on a collective holistic approach; this approach seems to be related to a collective professional competence and a common code of ethics that defines counsellors' professional turf and college in schools. The sense of 'us' in the 'collective mode' can contribute to safeguarding the pupil's best interests overall. Further, this mode could contribute to integrating professional (holistic approach) and managerial principles (separate counselling services) in what can resemble a form of hybrid professionalism (Noordegraaf, 2015). Such hybrid professionalism depends on collective-oriented schools (Irgens, 2010). Thus, the local conditions at each particular school will most likely have an impact on the counsellors' understanding, interpretations and practice (Liljegren, 2012). Hence, a collective-oriented school might contribute to a fruitful merge between policy measures with the aim of occupational professionalism and policy regarding organisational professionalism, creating a professional practice founded on a holistic view of counselling services as holistic practice.

Second, there is the separation designed with 'watertight bulkheads' and minimal contact between counsellors with different areas of responsibility. In terms of professional turfs and boundary work, we see the contours of a struggle taking place between career guidance and educational welfare. There appears to be a marked 'us' and 'them' between counsellors regarding these tasks rather than between the counselling services and the rest of the school. This seems to be conditioned by the organisational environment and the collaborative environment at the local school (Irgens, 2010).

Zacka (2017, p. 241) points out that 'whilst public service agencies actively depend on the moral agency of street-level bureaucrats, they place these bureaucrats in working conditions that tend to undermine that very agency'. Zacka emphasises that we need to 'evolve conditions where it is possible for them to fulfil their role adequately' (p. 241). 
Additionally, the resource situation in counselling services may affect the counsellors' interpretations. Their interpretations of and responses to policy recommendations may be coloured by scarce resources and the need to prioritise between the two equally important and demanding tasks of career counselling and educational welfare; this also comes into play when policy is to be implemented in the local school context.

The counsellors struggle with limited resources; they have a mean of 2.4 min per pupil per week in total at their disposal (Buland et al., 2020). Also, the narrative of educational welfare guidance with the ever-expanding needs related to pupils' mental and social challenges might cause conflicts between two equally important functions of counselling, which both have a part in a holistic approach to career guidance. This could eventually reduce the possibilities for synergy effects between the two functions of Norwegian school counselling, thus providing poorer services for the pupils because scarce resources force the street-level bureaucrats to prioritise their professional conduct.

\section{The pupil's best interest}

Although the outcome of the counsellors' interpretive processes are quite different, the ethical value of safeguarding the pupils' best interests appears as a common denominator. Hence, our analysis indicates that counsellors are dedicated to putting the pupils' needs at the core of their practices, despite differences in views on organising and scarce resources. Perhaps, this is what defines the core of occupational professionalism amongst Norwegian school counsellors: concern for the pupils' best interests. This would imply a common agreement of safeguarding the pupil's best interest as a moral compass for counsellors' professional conduct and in accordance with policy guidelines.

Tummers and Bekkers (2014) find that bureaucrat's perceptions of client meaningfulness strongly influenced their willingness to implement policy. Our study shows how the opposite of what Tummers and Bekkers (2014) have found: when counsellors interpret the recommended policy as a measure that will not be meaningful to their clients, they are less willing to implement it. Those counsellors who did not see separate counselling services as an organisational measure that is in the pupils' best interest or did not see how it could ensure a holistic approach were less willing to implement it. By resisting policy recommendations, they were attempting to safeguard the pupils' rights. Hence, the implication for policy intervention in school counselling is an orientation towards local understandings, here seeking to implement policy in ways that are recognised at the local schools as in the pupils' best interests. This resembles what the expert committee on the teachers role (2016, p. 208) recommends.

\section{Conclusion}

In the current study, we have explored how counsellors interpret and understand the recommendations for separating counselling services in schools. Our findings reveal three different approaches to these recommendations. The approaches appear 
as different outcomes of counsellors in encounters with interpretative flexible policy recommendations. The counsellors utilise their positions as street-level bureaucrats in their processes of interpretation, responding to the recommendation based on their judgement of what is in their pupils' best interest.

The present study was conducted in Norwegian schools. Hence, the specific characteristics of the Nordic context for guidance counselling may contain some limitations regarding the transferability of our findings. Further, participation was voluntary, and data were collected at a single point in time. Separate counselling services were only one part of the themes discussed in the focus group interviews. Thus, the current study might not capture every critical aspect of counsellors' interpretations of separate counselling services.

Areas for further research are to further explore the concept of interpretative flexibility in relation to policy implementations and street-level bureaucracy; this could provide insights into how to ensure the effective implementation of policy recommendations. Another interesting topic for research is whether individual- or collective-oriented schools have significance for practice development and policy implementation. Implications for practice are that school leaders, counsellors and policy makers need to recognise the ambiguities between policy and ethical values in guidance counselling and consider how local characteristics such as collectiveness or individualisation in schools might affect interpretation and responses to new policy interventions. Finally, we suggest that the findings of the present study may be relevant for the current process of implementing a new quality framework (Haug et al., 2019) for career guidance in Norwegian schools. This is because a successful implementation process would need to consider the interpretative flexibility of policy, counsellors' professional and ethical values and the local school contexts for implementation, along with how these elements affect how politics become a practice in each school.

Acknowledgements We would like to thank Trond Buland for valuable comments and discussions in the preparation of this article. We are also grateful to the counsellors for participating in the research and to NORCE Research AS who made the material available for further research.

Author contributions Both authors have made substantial contributions to the conception, analysis and interpretation of data; drafted the work and revised it critically for important intellectual content. Both authors approved the version to be published and agree to be accountable for all aspects of the work in ensuring that questions related to the accuracy or integrity of any part of the work are appropriately investigated and resolved.

Funding Open access funding provided by University Of Stavanger. The collection of data was funded by two sources: The counties of Sør-Trøndelag, Nord-Trøndelag and Møre og Romsdal in Norway and the Union of Education Norway. The preparation of this manuscript and research were supported by the University of Stavanger through a doctoral fellowship.

Data availability Research data are not shared.

Code availability Not applicable.

\section{Declarations}

Conflict of interest The authors declare that they have no conflict of interest. 
Open Access This article is licensed under a Creative Commons Attribution 4.0 International License, which permits use, sharing, adaptation, distribution and reproduction in any medium or format, as long as you give appropriate credit to the original author(s) and the source, provide a link to the Creative Commons licence, and indicate if changes were made. The images or other third party material in this article are included in the article's Creative Commons licence, unless indicated otherwise in a credit line to the material. If material is not included in the article's Creative Commons licence and your intended use is not permitted by statutory regulation or exceeds the permitted use, you will need to obtain permission directly from the copyright holder. To view a copy of this licence, visit http://creativecommons.org/licen ses/by/4.0/.

\section{References}

Abbott, A. (1988). The system of professions: An essay on the division of expert labor. University of Chicago Press.

Andreassen, I. H., Einarsdottir, S., Lerkkanen, J., Thomsen, R., \& Wikstrand, F. (2019). Diverse histories, common ground and a shared future: The education of career guidance and counselling professionals in the Nordic countries. International Journal for Educational Vocational Guidance, 19(3), 411-436. https://doi.org/10.1007/s10775-018-09386-9

Bakke, I. B. (2020). The "idea of career" and "a welfare state og mind". On th Nordic model for welfare and career. In E. H. Haug, T. Hooley, J. Kettunen, \& R. Thomsen (Eds.), Setting Nordic career guidance in context (pp. 23-36). Sense Publishers.

Betz, N. E., \& Corning, A. F. (1993). The inseparability of "Career" and "Personal" counseling. The Career Development Quarterly, 42(2), 137-142. https://doi.org/10.1002/j.2161-0045.1993.tb004 26.x

Brodkin, E. Z. (2012). Reflections on street-level bureaucracy: Past, present, and future. Public Administration Review, 72(6), 940-949.

Bronfenbrenner, U. (1977). Toward an experimental ecology of human development. American Psychologist, 32(7), 513-531. https://doi.org/10.1037/0003-066X.32.7.513

Buland, T. (1996). Den store planen: Norges satsing på informasjonsteknologi, 1987-1990 [The big plan: Norway's investment in information technology, 1987-1990]. Senter for teknologi og samfunn, NTNU.

Buland, T., \& Havn, V. (2003). De første skritt er tatt, veien videre venter? Sluttrapport fra evalueringen av prosjektet "Delt rådgivningstjeneste" (A03510). Retrieved from https://www.sintef.no/globa lassets/upload/teknologi_og_samfunn/gsu/delt-radgivningstjeneste.pdf.

Buland, T., Mathiesen, I. H., Mordal, S., Tønseth, C., Austnes-Underhaug, R., \& Skoland, K. (2014). " $E$

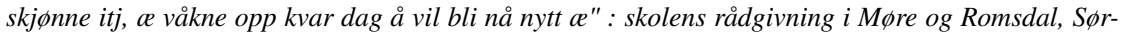
Trøndelag og Nord-Trфndelag (9788279230663). Retrieved from https://brage.bibsys.no/xmlui/bitst ream/handle/11250/2429527/skolens\%2Br\%25C3\%25A5dgivning\%2Bi\%2BST\%2BNT\%2Bog\% 2BMR82557.pdf?sequence $=2$.

Buland, T., Mordal, S., \& Mathiesen, I. H. (2020). Utdannings- og yrkesrådgiving og sosialpedagogisk rådgiving i norsk skole anno 2020. En kartlegging av ressurser og arbeidsoppgaver til rådgiving $i$ skolen $i$ Norge. Retrieved from https:/www.utdanningsforbundet.no/var-politikk/publikasjoner/ 2020/utdannings--og-yrkesradgiving-og-sosialpedagogisk-radgiving-i-norsk-skole-anno-2020.-enkartlegging-av-ressurser-og-arbeidsoppgaver-til-radgiving-i-skolen-i-norge/

Demant, J. (2006). Fokusgruppen - spørgesmål til fænomrnrt i nuet In O. Bjerg \& K. Villadsen (Eds.), Sociologiske metoder - fra teori til analyse $i$ kvantitative og kvalitative studier. Forlaget Samfundslitteratur.

Expert committee on the role of teachers (2016). Om larerrollen: et kunnskapsgrunnlag [The role of the teacher: a knowledge base].Fagbokforlaget.

Evetts, J. (2009). New professionalism and new public management: Changes, continuities and consequences. Journal of Comparative Sociology, 8(2), 247-266.

Frostenson, M. (2015). Three forms of professional autonomy: De-professionalisation of teachers in a new light. Nordic Journal of Studies in Educational Policy, 2015(2), 28464.

Haug, E. H., Hooley, T., Kettunen, J., \& Thomsen, R. (Eds.). (2020a). Career and career guidance in the Nordic countries. Sense Publichers. 
Haug, E. H., Hooley, T., Kettunen, J., \& Thomsen, R. (2020b). Setting Nordic career guidance in context. In E. H. Haug, T. Hooley, J. Kettunen, \& R. Thomsen (Eds.), Career and career guidance in the Nordic countries (pp. 1-20). Sense Publichers.

Haug, E. H., Plant, P., Valdimarsdottir, S. A., Bergmo-Prvulovic, I., Vuorinen, R., Loven, A., \& Vilhjalmsdottir, G. (2018). Nordic research on educational and vocational guidance: A systematic literature review of thematic features between 2003 and 2016. International Journal for Educational and Vocational Guidance, 19, 185-202.

Haug, E. H., Thomsen, R., Holm-Nordhagen, A., Schulstok, T., Gravås, T., Engh, L., Bakke, T., \& Gaarder, I. (2019). Nasjonalt kvalitetsrammeverk for karriereveiledning. Faglig forslag til områdene etikk, karrierekompetanse og kompetansestandarder. Retrieved from https://www.kompetansenorge. no/globalassets/karriere/rapport-nasjonalt-kvalitetsrammeverk-for-karriereveiledning.pdf.

Hermstad, I. H., Caspersen, J., \& Buland, T. (2020). Spenning og samspill når PPT skal tett på skolen. Psykologi i kommunen, 6.

Hooley, T. (2019). International approaches to quality in career guidance. Retrieved from https://www. kompetansenorge.no/globalassets/karriere/international-approaches-to-quality-in-career-guidance. pdf.

Hooley, T. (2020). Pining for the fjords. In E. H. Haug, T. Hooley, J. Kettunen, \& R. Thomsen (Eds.), Career and career guidance in the Nordic countries (pp. 37-50). Sense Publichers.

Hooley, T., \& Rice, S. (2019). Ensuring quality in career guidance: A critical review. British Journal of Guidance \& Counselling, 47(4), 472-486.

Hooley, T., Sultana, R., \& Thomsen, R. (2018). The neoliberal challenge to career guidance: mobilising research, policy and practice around social justice. In T. Hooley, R. Sultana, \& R. Thomsen (Eds.), Career guidance for socal justice - Contesting neoliberalism (pp. 1-27). Routledge.

Hughes, D., Meijers, F., \& Kuijpers, M. (2015). Testing times: Careers market policies and practices in England and the Netherlands. British Journal of Guidance Counselling, 43(2), 183-201.

Irgens, E. J. (2010). Rom for arbeid: Lederen som konstruktør av den gode skole. In R. A. Andreassen \& E. M. Skaalvik (Eds.), Kompetent skoleledelse. Tapir.

Irving, B. A. (2017). The pervasive influence of neoliberalism on policy guidance discourses in career/ education: Delimiting the boundaries of social justice in New Zealand. In T. Hooley, R. Sultana, \& R. Thomsen (Eds.), Career guidance for social justice contesting neoliberalism (pp. 47-62). Routledge.

Kettunen, J., \& Makela, J. P. (2019). Practitioners' conceptions of ethical practice in social networking in career services. International Journal for Educational and Vocational Guidance, 19(3), 345-362. https://doi.org/10.1007/s10775-018-9383-4

Krumboltz, J. D. (1993). Integrating career and personal counseling. The Career Development Quarterly, 42(2), 143-148.

Kunnskapsdepartementet [Ministry of Education] (2009). Forskrift om endring i forskrift til opplæringslova og forskrift til privatskolelova. Kapittel 22. [Regulations to the Education Act on the right to necessary counseling]. Retrieved from https://lovdata.no/dokument/LTI/forskrift/2008-12-19-1526.

Liljegren, A. (2012). Pragmatic professionalism: Micro-level discourse in social work. European Journal of Social Work, 15(3), 295-312. https://doi.org/10.1080/13691457.2010.543888

Lipsky, M. (1980). Street-level bureaucracy: Dilemmas of the individual in public services. Russell Sage Foundation.

Lipsky, M. (2010). Street-level bureaucracy: Dilemmas of the individual in public service (30th anniversary expanded). London: Sage.

Low, S. K., Kok, J. K., \& Lee, M. N. (2013). A holistic approach to school-based counselling and guidance services in Malaysia. School Psychology International, 34(2), 190-201.

Mathiesen, I. H., Mordal, S., \& Buland, T. (2014). En rådgiverrolle i krysspress? Lokal variasjon og konsekvenser for rådgivningen i skolen. Sosiologi i Dag, 44(4), 57-78.

Mordal, S., Buland, T. H., \& Mathiesen, I. H. (2015). Rådgiverrollen - mellom tidstyv og grunnleggende ferdighet (A26556). Retrieved from https://www.utdanningsforbundet.no/globalassets/var-politikk/ publikasjoner/eksterne-rapporter/radgiverrollen_sintef_mfl_januar-2015.pdf

Morgan, D. L. (2019). Basic and advanced focus groups. SAGE Publications.

Nilsen, A. C. E. (2021). Professional talk: Unpacking professional language. In P. C. Luken \& S. Vaughan (Eds.), Palgrave handbook of institutional ethnography. Palgrave Macmillian.

Noordegraaf, M. (2015). Hybrid professionalism and beyond: (New) Forms of public professionalism in changing organizational and societal contexts. Journal of Professions and Organization, 2(2), 187-206. https://doi.org/10.1093/jpo/jov002 
NOU 2016:7. Norge i omstilling - karriereveiledning for individ og samfunn. Kunnskapsdepartementet [Ministry of Education]. Retrieved from https://www.regjeringen.no/contentassets/05a79a5ed9 1e40e1a80e6f8028b21e3e/no/pdfs/nou201620160007000dddpdfs.pdf.

OECD. (2002). OECD Review of Career Guidance Policies. Norway Country Note. Retrieved from https://www.oecd.org/education/innovation-education/1937973.pdf.

Pinch, T., \& Bijker, W. (1987). The social construction of facts and artifats: Or how the sociology of science and the sociology of technology might benefit each other. In W. Bijker, T. Hughes, \& T. Pinch (Eds.), The social construction of technological systems. New directions in the sociology and history of thecnology. The MIT Press.

Plant, P., Christiansen, L. L., Loven, A., Vilhjalmsdottir, G., \& Vuorinen, R. (2003). Research in educational and vocational guidance in the Nordic countries: Current trends. International Journal for Educational and Vocational Guidance, 3, 101-122.

Rosvall, P. -Å. (2019). "The local place" in the pedagogic practices. In E. Öhrn \& D. Beach (Eds.), Young people's life an schooling in rural areas. The Tufnell Press.

St.Meld.nr.16. (2006-2007). ... og ingen sto igjen. Tidlig innsats for livslang laring. Kunnskapsdepartementet [Ministry of Education]. Retrieved from https://www.regjeringen.no/no/dokumenter/stmeldnr-16-2006-2007-/id441395/.

Sultana, R. G. (2009). Competence and competence frameworks in career guidance: Complex and contested concepts. International Journal for Educational and Vocational Guidance, 9(1), 15-30. https://doi.org/10.1007/s10775-008-9148-6

Sultana, R. G. (2018). Precarity, austerity and the social sontract in a liquid world: Career guidance mediating the citizen and the state. In T. Hooley, R. Sultana, \& R. Thomsen (Eds.), career guidance for social justice contesting neoliberalism (pp. 63-76). Routledge.

Super, D. E. (1993). The two faces of counseling: Or is it three? The Career Development Quarterly, 42(2), 132-136.

Tavory, I., \& Timmermans, S. (2014). Abductive analysis: Theorizing qualitative research. The University of Chicago Press.

Thomsen, R. (2014). Non-participation in guidance: An opportunity for development? International Journal for Educational and Vocational Guidance, 14(1), 61-76. https://doi.org/10.1007/ s10775-013-9260-0

Thomsen, R. (2017). Career guidance in communities: A model for reflexive practice. University of Derby.

Timmermans, S., \& Tavory, I. (2012). Theory construction in qualitative research: From grounded theory to abductive analysis. Sociological Theory, 30(3), 167-186.

Tummers, L., \& Bekkers, V. (2014). Policy implementation, street-level bureaucracy, and the importance of discretion. Public Management Review, 16(4), 527-547. https://doi.org/10.1080/14719037.2913. 841978

Watts, A. G. (2008). Career guidance and public policy. In J. A. Athanasou \& R. V. Esbroeck (Eds.), International handbook of career guidance. Springer.

Zacka, B. (2017). When the state meets the street: Public service and moral agency. Harvard University Press.

Zunker, V. G. (2012). Career counseling: A holistic approach (8th ed.). Cengage Learning.

Publisher's Note Springer Nature remains neutral with regard to jurisdictional claims in published maps and institutional affiliations. 